Submitted $30^{\text {th }}$ November 2020

Accepted $5^{\text {th }}$ Februari 2021

\title{
PENINGKATAN DAYA SAING UKM KOPI SEBAGAI PRODUK PENUNJANG PELAGA AGROTOURISM PARK
}

\author{
I Wayan Pantiyasa, Moh Agus Sutiarso', I Nyoman Arto Suprapto ${ }^{2}$ \\ ${ }^{12}$ Institut Pariwisata dan Bisnis Internasional, Denpasar \\ email:agussutiarso63@gmail.com
}

\begin{abstract}
ABSTRAK
Peningkatan daya saing UKM kopi penunjang pengembangan Pelaga Agrotourism Park berbasis masyarakat sangat diperlukan sebagai usaha pemberdayaan masyarakat lokal. Melalui kegiatan-kegiatan pendampingan dan pelatihan yang terarah sesuai dengan prioritas kebutuhan mitra diharapkan Program Pengembangan Desa Mitra (PPDM) yang dilaksanakan oleh tim dosen Institut Pariwisata dan Bisnis Internasional ini dapat mencapai target yang dicapai. Tujuan kegiatan pengabdian ini adalah meningkatkan kemampuan sumberdaya manusia dalam mengelola destinasi agrowisata berbasis masyarakat melalui peran aktif pemangku kepentingan yang ada di desa Pelaga termasuk UKM kopi. Melalui pendampingan yang dilakukan oleh tim pelaksana telah berhasil dilakukan peningkatan hyginitas proses produksi dan perbaikan kemasan produk kopi bubuk dengan menggunakan label Pelaga Agrotourism Park. Kerjasama pemasaran dengan Koperasi Pegawai Negeri dan promosi melalui media sosial juga telah dilakukan, dan berdampak pada peningkatan produksi sekaligus peningkatan pendapatan.
\end{abstract}

\section{Kata Kunci: UKM Kopi, Pelaga Agrotourism Park, Pemberdayaan Masyarakat Desa}

\section{PENDAHULUAN}

Dataran tinggi Pelaga sangat cocok bagi pertumbuhan tanaman kopi. Luas tanam kopi di desa Pelaga pada tahun 2019 merupakan yang terluas di kecamatan Petang mencapai 6.301 hektar dengan produksi mencapai 1.071 ton (BPS Kabupaten Badung, 2020). Produk unggulan pertanian di desa ini menjadi sasaran kegiatan pengabdian masyarakat dalam Program Pengembangan Desa Mitra (PPDM) Agroturism Park di tahun 2020. Cita rasa kopi yang diproduksi oleh para petani yang tergabung dalam kelompok petani kopi Giri Tani desa Pelaga ini tidak kalah nikmat dengan kopi yang terlebih dahulu tersohor seperti kopi Gayo atau kopi Toraja. Melalui program pengabdian masyarakat ini diharapkan kopi Pelaga nantinya menjadi salah satu kopi terbaik Nusantara.

Pengembangan Agrotourism Park di desa Pelaga yang terletak di dataran tinggi kabupaten Badung bagian Utara ini dilakukan dengan melibatkan komponen yang ada di masyarakat. Keterlibatan ini diharapkan akan mengangkat pengetahuan lokal dan kearifan tradisional yang sudah eksis di masyarakat, dan berusaha untuk meningkatkan keunggulan-keunggulan potensi agrowisata yang dimiliki masyarakat termasuk usaha kecil menengah (UKM) penunjang wisata berbasis pertanian melalui program pendampingan dan pelatihan.

UKM memiliki peran yang sangat strategis dalam pengembangan dunia usaha, dan merupakan salah satu program pemerintah dalam meningkatkan kesejahteraan masyarakat, mengingat kemampuan bertahannya dalam kondisi apapun. UKM juga merupakan salah satu alternatif untuk mengatasi pengangguran. 
Pengembangan UKM kopi sebagai penunjang agrowisata di desa Pelaga perlu ditingkatkan mengingat dampaknya bagi perluasan lapangan kerja dan memberikan pelayanan ekonomi yang luas pada masyarakat, sehingga terjadi pemerataan dalam pertumbuhan ekonomi dan pendapatan masyarakat.

Permasalahan yang ditemui di lapangan terkait keberadaan UKM kopi sebagai pendukung Agrotourism Park ini adalah masih rendahnya performance dan daya saing produk UKM kopi yang dihasilkan oleh kelompok petani kopi (pengolah kopi bubuk) yang tergabung dalam Kelompok Petani Kopi Giri Tani.

Peningkatan daya saing UKM kopi untuk pengembangan Pelaga Agrotourism Park berbasis masyarakat sangat diperlukan sebagai usaha pemberdayaan masyarakat lokal. Melalui kegiatan-kegiatan pendampingan dan pelatihan yang terarah sesuai dengan prioritas kebutuhan mitra diharapkan Program Pengembangan Desa Mitra (PPDM) yang dilaksanakan oleh tim dosen Institut Pariwisata dan Bisnis Internasional ini dapat mencapai target yang dicapai dan sekaligus merupakan tujuan kegiatan pengabdian ini yaitu meningkatnya kemampuan sumberdaya manusia dalam mengelola destinasi agrowisata berbasis masyarakat melalui peran aktif pemangku kepentingan yang ada di desa Pelaga termasuk UKM kopi.

Tujuan kegiatan pengabdian ini adalah meningkatkan kemampuan sumberdaya manusia dalam mengelola destinasi agrowisata berbasis masyarakat melalui peran aktif pemangku kepentingan yang ada di desa Pelaga termasuk UKM kopi.

\section{METODE}

Kegiatan Program Pengembangan Desa Mitra (PPDM) ini merupakan kegiatan multi tahun dan dilaksanakan selama tiga tahun (2019-2021). Untuk tahun kedua (2020), bentuk kegiatan yang dilakukan disesuaikan dengan prioritas permasalahan yang dihadapi oleh mitra sasaran, setelah mengobservasi dan melakukan pertemuan-pertemuan kecil dengan kelompok mitra yang terdiri dari Pokdarwis, PKK, dan Kelompok Petani Kopi. Pada laporan kegiatan ini khusus membahas tentang peningkatan daya saing UKM kopi sebagai produk penunjang Pelaga Agrotourism Park.

Berhubung adanya wabah pandemi Covid-19 yang melanda di seluruh dunia ini, maka pelaksanaan kegiatan dilakukan mengikuti protokol kesehatan yang telah ditetapkan oleh Pemerintah.

Tabel 1. Kelompok Mitra Sasaran Program dan Bentuk Kegiatan Pada Tahun 2020

\begin{tabular}{|c|c|c|c|c|}
\hline No & $\begin{array}{c}\text { Kelompok } \\
\text { Mitra Sasaran }\end{array}$ & Permasalahan & $\begin{array}{c}\text { Solusi } \\
\text { Permasalahan }\end{array}$ & $\begin{array}{c}\text { Bentuk } \\
\text { Kegiatan }\end{array}$ \\
\hline & $\begin{array}{l}\text { Kelompok } \\
\text { Petani Kopi } \\
\text { (Giri Tani) }\end{array}$ & 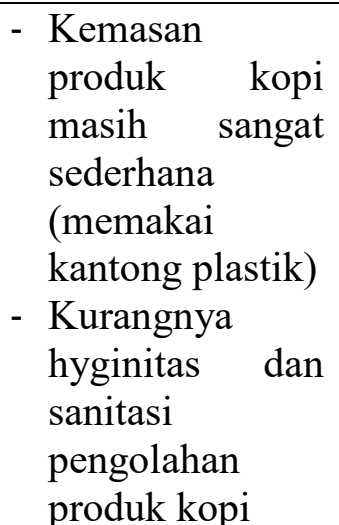 & $\begin{array}{l}\text { - } \text { Meningkatkan } \\
\text { performance } \\
\text { produk kopi } \\
\text { - Meningkatkan } \\
\text { pemasaran }\end{array}$ & $\begin{array}{l}\text { - Pendamping } \\
\text { an } \\
\text { pembuatan } \\
\text { label dan } \\
\text { kemasan } \\
\text { produk kopi } \\
\text { - Pendamping } \\
\text { an } \\
\text { penanganan } \\
\text { hyginitas } \\
\text { dan sanitasi }\end{array}$ \\
\hline
\end{tabular}




\begin{tabular}{|l|l|l|l|}
\hline & - Kurangnya & & produk \\
& saluran & & olahan kopi \\
& pemasaran & & - Pendamping \\
produk kopi & & an \\
& & & pembuatan \\
& & & parana \\
& & & promosi dan \\
& & & perjasama \\
& & & \\
\hline
\end{tabular}

\section{HASIL DAN PEMBAHASAN}

Kegiatan pengabdian masyarakat pada tahun kedua ini dilaksanakan di tengah situasi pandemi virus Corona (Covid-19). Oleh karena itu bentuk kegiatan yang dilaksanakan juga memperhatikan protokol kesehatan yang telah ditetapkan Pemerintah, agar dapat menekan penyebaran virus Covid-19 di tengah masyarakat.

Untuk program di tahun kedua ini (2020) dalam rangka pengembangan destinasi Pelaga Agrotourism Park, kegiatan yang melibatkan peran Pokdarwis yaitu berupa penataan sarana wisata minat khusus (camping ground), pembuatan paket wisata trekking menyusuri hutan lindung yang berada di wilayah Desa Pelaga, dan pembuatan sarana promosi wisata melalui media online (medsos). Sedangkan kegiatan yang melibatkan kelompok UKM berupa peningkatan daya saing dan performance produk antara lain perbaikan kemasan, peningkatan kualitas produk dan pemasaran produk.

Sesuai dengan potensi pertanian yang dimiliki, di Desa Pelaga terdapat beberapa UKM antara lain: kelompok petani kopi Giri Tani (pengolah biji kopi menjadi kopi bubuk), kelompok Koperasi usaha Asparagus, dan kelompok pengolah pangan PKK (pengolah umbi talas menjadi produk kripik talas).

Melalui kegiatan pendampingan, untuk tahun kedua ini telah dilakukan perbaikan pengemasan produk yang dihasilkan oleh UKM kopi dengan mengusung merk produk "Pelaga Agrotourism Park" pada setiap kemasan produk. Hal ini dilakukan dalam rangka memperkenalkan Desa Pelaga sebagai destinasi agrowisata melalui produk-produk unggulan pertanian yang dimiliki.

Brand dalam suatu destinasi wisata sangat diperlukan untuk menghadapi persaingan. Salah satu persaingan yang terjadi antar destinasi adalah tidak dikenalnya suatu destinasi dibandingkan dengan destinasi lain, padahal kedua destinasi tersebut menawarkan produk yang serupa, atau berbeda namun dengan keunikan masing-masing. Brand destinasi dapat mempermudah wisatawan untuk membedakan suatu destinasi dengan destinasi lainnya. Penggunaan nama dan logo "Pelaga Agrotourism Park" sebagai brand destinasi bertujuan untuk memperkenalkan produk destinasi agrowisata di desa Pelaga serta mengkomunikasikan keunikan destinasi tersebut secara visual, sehingga memudahkan destinasi untuk menjual produknya ke pasar pariwisata.

Pendampingan terhadap kelompok petani kopi Giri Tani di desa Pelaga dilakukan sebagai upaya untuk menunjang kepariwisataan di desa Pelaga yang mengusung tema agrowisata. Peningkatan performance produk kopi bubuk dilakukan dengan memperbaiki kemasan dari yang sebelumnya hanya dikemas dalam kantong plastik tipis dan hanya diikat tanpa label, ditingkatkan penampilannya dalam beberapa pilihan kemasan berlabel "Pelaga Agrotourism 
Park", yaitu: a) kemasan kertas berlapis aluminium foil, b) kemasan plastik pounch, c) kemasan plastik tebal yang telah dipres. Pada kesempatan ini tim pelaksana memberikan bantuan alat berupa alat pengepres kemasan produk kopi bubuk, timbangan pegas, serta pembuatan papan nama Sentra UKM Kopi Pelaga.

Prinsip dasar kemasan pangan adalah harus dapat melindungi produk yang dikemas dari berbagai kerusakan dari mulai selesai proses produksi, selama distribusi dan penjualan. Kemasan juga berfungsi sebagai media promosi bagi produk yang dikemas. Oleh karena itu diupayakan disain kemasan perlu dibuat semenarik mungkin, baik dari material kemasan maupun dari segi grafis. Melalui kemasan juga dapat ditingkatkan daya saing produk di pasar, karena menyangkut layak dan tidak layak menurut konsumen yang dituju, dan dapat mempengaruhi keputusan membeli.

Pendampingan dalam upaya peningkatan hyginitas dan sanitasi pengolahan produk kopi bubuk dilakukan dengan langsung mengunjungi tempat produksi kopi bubuk milik kelompok petani kopi "Giri Tani". Arahan dan praktek perbaikan hygitas dan sanitasi langsung diimplementasikan di rumah produksi berupa kebersihan alat dan bangunan serta standar pakaian pekerja.
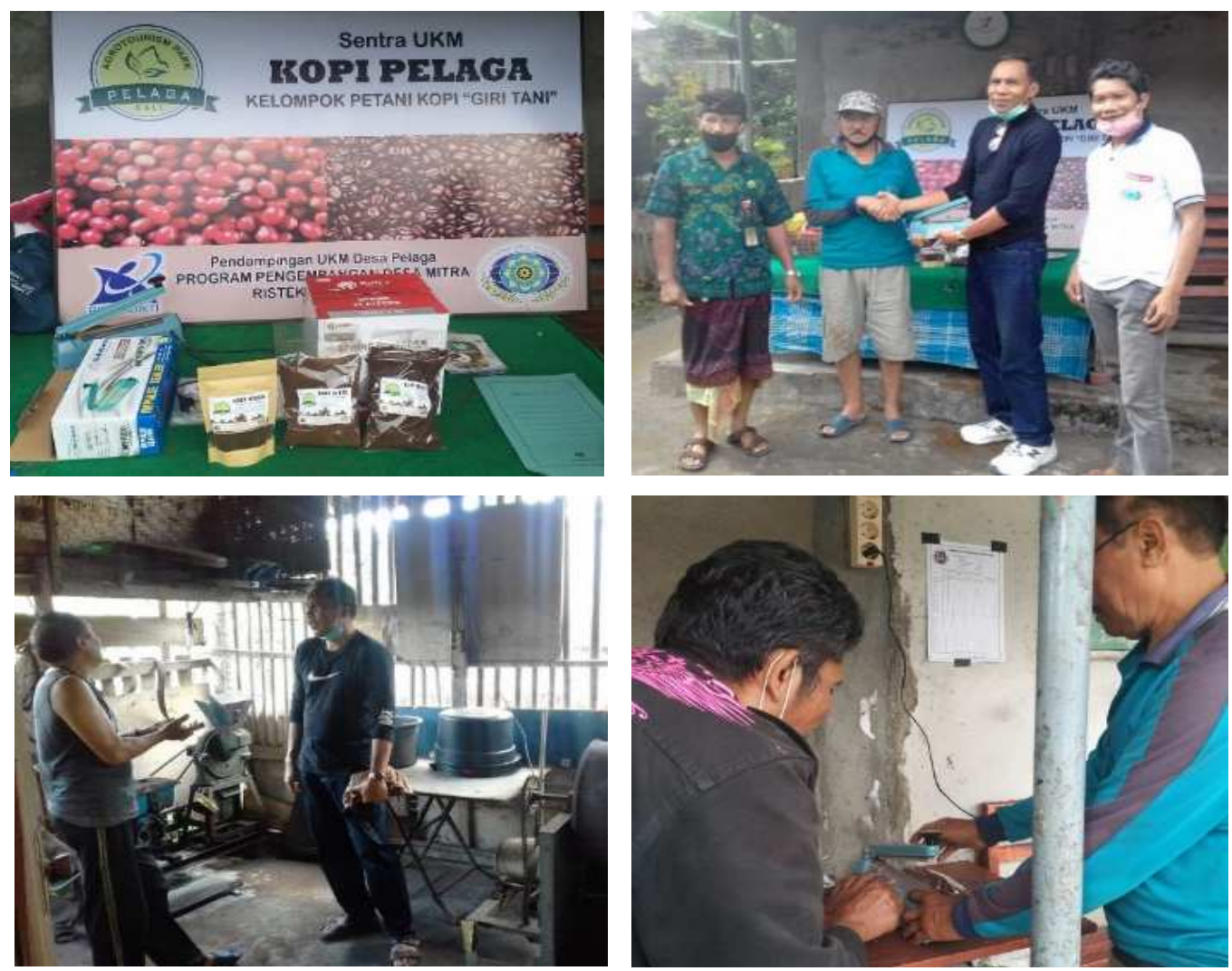

Gambar 1. Pendampingan UKM Kopi Pendukung Agrotourism Park

Upaya peningkatan pemasaran produk UKM kopi desa Pelaga dilakukan melalui kegiatan pendampingan berupa menjembatani kerjasama pemasaran dengan Koperasi Pegawai Negeri (KPN) Pemerintah Kabupaten Badung. Produk kopi bubuk yang telah dikemas dengan label Pelaga Agrotourism Park ini telah dipajang di rak penjualan KPN Pemkab Badung, dan telah memberikan peningkatan pendapatan bagi UKM kopi. Peningkatan pendapatan ini diperoleh 
dengan semakin meningkatnya produksi kopi bubuk untuk memenuhi permintaan yang mencapai $100 \mathrm{~kg}$ per bulan dari sebelumnya $60 \mathrm{~kg}$ per bulan (peningkatan sebesar $66 \%$ per bulan).

Selain kerjasama pemasaran dengan KPN Pemkab Badung, juga telah dilakukan promosi bersama pemangku kepentingan Pelaga Agrotourism Park lainnya (Pokdarwis) di internet melalui Channel Youtube, Instagram dan Facebook, yang diberi nama "Pelaga Agrotourism Park".

\section{SIMPULAN}

Dari hasil kegiatan pengabdian masyarakat di tahun kedua (2020) yang dilaksanakan di Desa Pelaga dalam rangka membangun "Pelaga Agrotourism Park" dapat disimpulkan bahwa perbaikan hygine dan sanitasi proses produksi dan perbaikan kemasan produk UKM kopi sebagai usaha penunjang wisata yang mengusung destination branding "Pelaga Agrotourism Park" dapat meningkatkan daya saing dan sangat membantu pemasaran produk UKM yang bersangkutan dan destinasi agrowisata di Desa Pelaga.

Adanya hasil nyata kegiatan pengabdian ini menunjukkan bahwa kegiatan tahun kedua Program Pengembangan Desa Mitra (PPDM) yang telah dilaksanakan di Desa Pelaga ini telah berhasil memberikan manfaat bagi masyarakat dan masyarakat masih mengharapkan adanya keberlanjutan dari program yang telah dicanangkan.

\section{UCAPAN TERIMAKASIH}

Tim pelaksana pengabdian kepada masyarakat PPDM "Pelaga Agrotourism Park" mengucapkan terima kasih yang tak terhingga kepada Kementerian Ristekdikti atas dana hibah yang dikucurkan untuk kegiatan ini. Terima kasih juga kami haturkan kepada Rektor Institut Pariwisata dan Bisnis Internasional, Dinas Pariwisata Kabupaten Badung, Dinas Koperasi dan UKM Kabupaten Badung, Perbekel, serta masyarakat Desa Pelaga.

\section{DAFTAR PUSTAKA}

Almayda, M., 2017. Place Branding in Tourism: A Review of Theoretical Approach and Management Practices. Tourism \& Management Studies, 13(4). pp. 1019. (available at https://dialnet.unirioja.es).

BPS Kabupaten Badung, 2020. Kecamatan Petang dalam Angka 2020. BPS Kabupaten Badung. Mangupura.

Kementerian Desa Pembangunan Daerah Tertinggal dan Transmigrasi RI. 2016. Pendampingan Desa - Modul Pelatihan Pratugas Pendamping Lokal Desa. Jakarta.

Kementerian Pariwisata RI. 2019. Buku Panduan Pengembangan Desa Wisata Berbasis Pendampingan Melalui Perguruan Tinggi. Jakarta.

Pantiyasa, IW., 2011. Pengembangan Pariwisata Berbasis Masyarakat (Community Based Tourism) Dalam Pemberdayaan Masyarakat - Studi Kasus di Desa Bedulu, Blahbatuh, Gianyar. Jurnal Ilmiah Hospitality Management, I(2).

Pantiyasa, IW., 2019. Konstruksi Model Pengembangan Desa Wisata Menuju Smart Eco-Tourism di Desa Paksebali, Klungkung, Bali. Jurnal Kajian Bali. IX(1), pp. 165-188. 
Pitana, IG., 1999. Pelangi Pariwisata Bali - Kajian Aspek Sosial Budaya Kepariwisataan Bali di Penghujung Abad. Denpasar: Penerbit BP.

Sutiarso, MA., 2020. Membangun Agrotourism Park Berbasis Masyarakat. Dalam Sutiarso, MA (Editor). Manajemen Pariwisata - Sebuah Tinjauan Teori dan Praktis. Penerbit Widina Bhakti Persada Bandung.

Sutiarso, MA., 2018. Kriteria Pengembangan Desa Pelaga Sebagai Destinasi Agropark di Kabupaten Badung. DwijenAgro. VIII(2), pp. 220-225. 